\title{
Coping as Predictor of Organizational Commitment of Police Employees
}

\author{
Abhay Pratap Singh ${ }^{1 *}$
}

\section{ABSTRACT}

The present study investigate the impact of coping strategies on organizational commitment of employees working at different hierarchical level i.e., police officers, sub-inspectors and constables. A sample of 240 employees working at different hierarchical level was assessed on the measures of coping scale and organizational commitment questionnaire. Step-wise multiple regression analysis revealed that a different set of predictors of organizational commitment was obtained for employees working at deferent hierarchical level. On police officers, positive reframing, planning and use of instrumental support coping strategies played as favorable role for increasing commitment level. However, religion played favorable role for uplifting the level of commitment of police sub- inspectors. But coping strategies had no significant favorable role on commitment of constables. However, maladaptive coping strategies were played unfavorable role for increasing the level commitment in all cadre of police employees. Results have been discussed in the light of personal and organizational factors.

Keywords: Predictor, Organizational, Police Employees

Police employees of all cadres are trained to provide us security and protect our rights and maintain law and order in the society. They are problem solvers for any piece of population. For that they have to control their emotions at work situation and avoid some social and personal roles to fulfill the given responsibilities. They have undesirable schedule in their profession and this undesirability decreases the level of commitment towards organization. Besides, consistence failure in coping with routine excess and problematic work pulls down the commitment level of police employees. Thus, there is need for using best coping strategies of every employee for well performance and commitment.

In the present scenario, highly committed and skilled employees play an important role in every organization. Committed employees think straight and synergistically, and this aids them in

\footnotetext{
${ }^{1}$ Assistant Professor, Psychology, Akhilabhagya Post Graduate College Ranapar, Gorakhpur, India *Responding Author

(C) 2016, A Singh; licensee IJIP. This is an Open Access Research distributed under the terms of the Creative Commons Attribution License (http://creativecommons.org/licenses/by/2.0), which permits unrestricted use, distribution, and reproduction in any Medium, provided the original work is properly cited.
} 


\section{Coping as Predictor of Organizational Commitment of Police Employees}

evolving effective strategies and unblocking the organizational potential for problem solving. The psychological bond between employee and employer is very important predictor of work related attitudes and behaviors (Mathieu and Zajac, 1990; Meyer, Stanley, Herscovitch and Topolnytsky, 2002; Mowday, Porter and Steers,1982; Van Dick, 2004 ). Research showed that employee with stronger organizational commitment find work more meaningful a are more determined to work well even in difficult situations (Ion and Huang, 2007; Sinclair, Tucker, Cullen and wright, 2005). Meyer and Allen,(1991,1997) and Meyer and Herscovitch (2001) compiled a list of definitions of organizational commitment and analyzed the similarities and differences. The similarities served as the basis for a definition of what they consider the 'core essence' of commitment: Commitment is a force that binds an individual to a course of action that is of relevance to a particular target' (Meyer and Herscovitch, 2001). Although approaches to the definition of organizational commitment vary considerably, certain trends are evident. The various definitions share a common theme, which indicates that organizational commitment is a liking of individual to the organization.

In the present study coping is considered as second variable. Lazarus and Folkman (1984) defined 'Coping is a person's constantly changing cognitive and behavioral effort to manage specific external and/ or internal demands that is appraised as taxing or exceeding the resources of the person.' Cohen and Lazarus (1979) suggested five main tasks of coping; to reduce harmful environmental conditions and enhance prospects of recovery, to make positive self image, to maintain emotional equilibrium and to continue satisfying relationship with others.

The relationships between various personal factors and organizational commitment have probably been more widely studied. Commitment has been shown to be positively related to age (Angle and perry,1981; Meyer and Allen, 1984; Morris and Sherman, 1981; Steers, 1977) and tenure (Buchanan, 1974; Meyer and Allen , 1984; Mottaz, 1988; Mowday, Steers and Porter, 1979; Singhal and Sood, 1981). Mathieu and Zajac (1990) found medium positive correlation between age and commitment. Studies show that work values, need and outlooks change as the employees grow older. Career stage brings differences in promotion opportunities and retirement benefits (Super, 1980). There are many studies which examined the effect of employee's age on various job attitudes. A study conducted by Sharma and Kapoor (1978) revealed that age and length of service were positively associated with job involvement. Sharma and Sharma (1978) reported similar findings of an association between job involvement and age and service period. Das (1983) pointed out that length of service is positively correlated to job involvement. Pandey and Mandal (1990) found that older employees were more satisfied than younger ones.

Besides, the literature suggests that an employee's personality and attribution processes may be an important antecedent to commitment. Employee's locus of control and coping are most important personal antecedents to commitment. Singh (2010) opined that active and adaptive related coping strategies were positively linked with all component of organizational 


\section{Coping as Predictor of Organizational Commitment of Police Employees}

commitment. Tiwari (2006) found close linkages between coping and organizational commitment. Another studies, it has been found that there is positive relationship between the personal attribution of internality and organizational commitment (Achamamba and Gopikumar, 1990; Spector, 1982). Studies reveal that locus of control is associated with various other job attitudes. It has been found that those who have an internal locus of control expressed higher job involvement (Pathak, 1982). Padaki (1982) found that internals are more satisfied with their job. Kulkarni (1980, 1983) also reported negative relationship between externality and job satisfaction among officers. Suman and Srivastava (2012) also reported major impact of various personal and organizational characteristics on organizational commitment of employees working at different hierarchical level.

Above reviews of literature suggest that a number of studies have been conducted examining the relationship between organizational commitment and personal factors in different occupational settings. But relative contribution of coping strategies on overall organizational commitment across different hierarchy of police personnel is rarely investigated issue in context of Indian Police. The present study is a modest attempt in this direction.

\section{Objective}

To find out the relative contribution of coping strategies on overall organizational commitment across various hierarchy of police employees

\section{Hypothesis}

Based on the above objective following hypothesis has been developed

- $\quad$ Certain coping strategies would emerge as significant predictors of overall organizational commitment of police personnel.

\section{METHOD}

\section{Participants}

The study was conducted on police department of Gorakhpur Zone. A total of 240 male police personnel participated as respondents from three cadres i.e., officers, sub inspectors and constables. Stratified random sampling technique was used in the present study. The sample was taken from the different police stations, traffic office, fire stations, PAC offices etc. of Gorakhpur Zone (India), as well as employees and officers of all offices of higher authorities were also participated.

\section{Measures}

Cope Scale: This scale, developed and standardized by Carver, Scheiver and Weintraub (1989) was applied to assess coping styles and strategies of police personnel. This scale includes 15 coping strategies to measure three types of coping styles i.e., active, adaptive and maladaptive coping.

(C) The International Journal of Indian Psychology, ISSN 2348-5396 (e)| ISSN: 2349-3429 (p) | 193 


\section{Coping as Predictor of Organizational Commitment of Police Employees}

Organizational Commitment Scale (OCS): The revised scale of organizational commitment (Allen \& Meyer, 1990a) was used to ascertain the level of organizational commitment of police employees. The original scale comprises of 8 items each (Allen \& Meyer, 1990a) on the three dimensions. The revised scale comprises of 6 items on each of the three dimensions and hence, consists of 18 items. To adapt in Indian culture the English version of the Meyer, Allen and Smith (1993) scale was translated in Hindi and finally, Indian adaptation of organizational commitment scale, made by Khan and Mishra, (2002) was used in this study. This scale contains three components of commitment i.e. Affective, Continuance and Normative.

Originally, the scale was 7 point Likert Scale. The scaling was changed into 5 point scale with anchors labeled ( 5 = strongly agree and $1=$ strongly disagree). There were four negatively worded items, three in affective commitment and one in normative commitment sub-scales. The negatively worded items are to be scored in reverse order i.e., 5, 4, 3, 2, 1 order. The responses of the identified items were added to generate dimension wise and overall organizational commitment. Thus, the possible score for commitment sub scale would be 6 to 30 and for overall organizational commitment scale from 18 to 90 . High score indicates high level of agreement and low score indicates low agreement on commitment dimensions in the organization.

\section{Procedure}

Respondents were contacted at their workplaces. They were introduced about the problem of the study. Each participant was promised that his personal views and information would not be disclosed at any cost. After receiving the initial willingness of the respondents to participate in the study, their background information's were collected on the basis of Personal Data Sheet (P.D.S). Then, they were requested to respond on organizational commitment scale and as they completed their responses on this scale again they were requested to respond on coping scale. As soon as, they completed their responses on above said measures, filled measures and answer sheets were collected and respondents were thanked for participation. Answer sheets were scored according to defined rules as given in manuals. Obtained scores were analyzed with the help of SPSS $17^{\text {th }}$ version.

\section{RESULTS}

To examine the relative effect as well as the direction of the effect of coping responses on organizational commitment of three hierarchical groups of employees, step - wise multiple regression analyses were used. In the step-wise multiple regression analysis, the contribution of a given predictor is determined by partial out the effect of remaining predictors. Thus, in this strategy the relative importance of predictors depends on its independent contribution to the criterion. The proportion of variance in the criterion, which is jointly explained by two or more predictors, is not considered in this process. In such analysis, the relative strength of predictors and their direction of contribution are determined by standardized regression co efficient. Apart 


\section{Coping as Predictor of Organizational Commitment of Police Employees}

from this, the aforesaid analysis also gives information regarding the joint contribution of the predictors (the value of $\mathrm{R}^{2}$ ) in the criterion.

\section{The Relative Strength of Coping Strategies in Predicting Organizational Commitment of} the Police Officers

In order to examine the relative contributions of coping strategies on organizational commitment of police officers, step-wise multiple regression analyses were computed. Obtained results have been recorded in Tables.

Table 1: Step- wise multiple regression analysis for commitment of police officers on to the coping responses

\begin{tabular}{|l|r|r|r|r|r|r|}
\hline \multirow{2}{*}{$\begin{array}{l}\text { Predictor Variables } \\
\text { (Dimensions of coping) }\end{array}$} & \multicolumn{6}{|c|}{ Criterion (Overall Commitment) } \\
\cline { 2 - 7 } & $\mathbf{R}$ & $\mathbf{R}^{2}$ & \multicolumn{1}{c|}{$\begin{array}{c}\mathbf{R}^{2} \\
\text { Change }\end{array}$} & $\begin{array}{c}\text { Beta } \\
\boldsymbol{\beta}\end{array}$ & \multicolumn{1}{c|}{$\mathbf{t}$} & \multicolumn{1}{c|}{$\mathbf{F}$} \\
\hline Humor & .765 & .586 & .586 & -.765 & -.10 .500 & $110.260^{* *}$ \\
\hline Drug & .833 & .694 & .108 & -.351 & -5.208 & $87.156^{* *}$ \\
\hline Positive Reframing & .847 & .718 & .024 & .189 & 2.553 & $64.438^{* *}$ \\
\hline Planning & .866 & .751 & .033 & .218 & 3.151 & $56.490^{* *}$ \\
\hline Use of Instrumental Support & .898 & .806 & .055 & .267 & 4.573 & $61.370^{* *}$ \\
\hline Behavioral Disengagement & .919 & .844 & .038 & -.223 & -4.233 & $65.820^{* *}$ \\
\hline Denial & .940 & .883 & .039 & -.222 & -4.916 & $77.771^{* *}$ \\
\hline Focus on and venting emotion & .946 & .895 & .012 & .152 & 2.827 & $75.654^{* *}$ \\
\hline
\end{tabular}

Examination of the standardized regression coefficients are shown in table suggest that Humor was the negatively most dominant predictor $\left(\beta=-.765, \mathrm{R}^{2}=.586\right)$ of normative commitment followed by drug $\left(\beta=-.351, R^{2}=.694\right)$ behavioral disengagement $\left(\beta=-.223, R^{2}=.844\right)$ and denial $\left(\beta=-.222, R^{2}=.883\right)$. However, positive reframing $\left(\beta=.189, R^{2}=.718\right)$, planning $\left(\beta=.218, R^{2}=\right.$ .751 ), use of instrumental support $\left(\beta=.267, \mathrm{R}^{2}=.806\right)$ and focus on and venting emotion ( $\beta=$ $.152, \mathrm{R}^{2}=.895$ ) contributed positively. Though independently Humor explained 58.6\%, drug explained $10.8 \%$, positive reframing explained $2.4 \%$, planning coping explained $3.3 \%$, use of instrumental support explained 5.5\%, behavioral disengagement explained $3.8 \%$, denial explained 3.9\%, and focus on and venting emotion explained $1.2 \%$ in criterion variables . But the composite contribution of these variables was found $89.5 \%$ variance on overall commitment of police officers. 


\section{Coping as Predictor of Organizational Commitment of Police Employees}

Table 2: Step- wise multiple regression analysis for commitment of sub-inspectors on to the coping responses

\begin{tabular}{|l|r|r|r|r|r|r|}
\hline \multirow{2}{*}{$\begin{array}{l}\text { Predictor Variables } \\
\text { (Dimensions of coping) }\end{array}$} & \multicolumn{6}{|c|}{ Criterion ( Overall Commitment ) } \\
\cline { 2 - 7 } & $\mathbf{R}$ & $\mathbf{R}^{2}$ & $\begin{array}{c}\mathbf{R}^{2} \\
\text { Change }\end{array}$ & $\begin{array}{c}\text { Beta } \\
\boldsymbol{\beta}\end{array}$ & \multicolumn{1}{c|}{$\mathbf{~}$} & \multicolumn{1}{c|}{$\mathbf{F}$} \\
\hline Drug & .323 & .104 & .104 & -.323 & -3.014 & $9.085^{* *}$ \\
\hline Religion & .432 & .187 & .083 & .300 & 2.796 & $8.848^{* *}$ \\
\hline Denial & .489 & .239 & .052 & -.245 & -2.281 & $7.955^{* *}$ \\
\hline
\end{tabular}

Regression results revealed that overall commitment was also predicted by three factors. Drug was negatively contributed $\left(\beta=-.323, R^{2}=.104\right)$, followed by denial $\left(\beta=-.245, R^{2}=\right.$ .239). whereas religion coping predicted positively $\left(\beta=.300, \mathrm{R}^{2}=.187\right)$. Though independently drug explained $10.4 \%$, religion explained $8.3 \%$ and denial also explained $5.2 \%$. But the composite contribution of these variables was found $23.9 \%$ variance on overall commitment of sub-inspectors.

Table 3: Step- wise multiple regression analysis for commitment of constables on to the coping responses

\begin{tabular}{|l|r|r|r|r|r|r|}
\hline \multirow{2}{*}{$\begin{array}{l}\text { Predictor Variables } \\
\text { (Dimensions of coping) }\end{array}$} & \multicolumn{6}{|c|}{ Criterion (Overall Commitment) } \\
\cline { 2 - 7 } & $\mathbf{R}$ & $\mathbf{R}^{2}$ & $\begin{array}{c}\mathbf{R}^{2} \\
\text { Change }\end{array}$ & $\begin{array}{c}\text { Beta } \\
\boldsymbol{\beta}\end{array}$ & $\mathbf{1}$ & $\mathbf{F}$ \\
\hline Behavioral Disengagement & .347 & .120 & .120 & -.347 & -3.268 & $10.682^{* *}$ \\
\hline Focus on and venting emotion & .416 & .173 & .052 & -.232 & -2.209 & $8.047^{*}$ \\
\hline
\end{tabular}

Results revealed that overall commitment was also predicted by two factors. Behavioral disengagement was negatively contributed $\left(\beta=-.347, \mathrm{R}^{2}=.120\right)$, followed by focus on and venting emotion $\left(\beta=-.232, \mathrm{R}^{2}=.173\right)$. Though independently behavioral disengagement explained $12 \%$ and focus on and venting emotion explained 5.2\%. But the composite contribution of these variables was found $17.2 \%$ variance on overall commitment of constables.

\section{DISCUSSION}

In the present study an attempt was made to examine how and to what extent fifteen coping strategies are important in determining the organizational commitment of police employees. Basically, these employees were categories under three cadre i.e., officers, sub - inspectors and constables. Positive reframing, planning and use of instrumental support contributed maximum favorably, however humor, drug, behavioral disengagement, denial and focus on and venting emotion played unfavorable role in making organizational commitment for police officers. Whereas, religion predicted positively but drug and denial coping strategies significantly

(C) The International Journal of Indian Psychology, ISSN 2348-5396 (e) | ISSN: 2349-3429 (p) | 196 


\section{Coping as Predictor of Organizational Commitment of Police Employees}

predicted negatively to organizational commitment of sub- inspectors. Furthermore, in constables group behavioral disengagement and focus on and venting emotion contributed very negatively to orient high organizational commitment level.

The obtained results of the present study was found that officers were using maximum active and adaptive related coping strategies as compared to sub- inspectors and constables.

Present finding was supported by earlier researches (Cohen, 1992; Tiwari, 2006; Tiwari \& Mishra 2008; Suman \& Srivastava, 2012; Singh, 2010). Since coping is a cognitive variable and commitment is considered as a motivational factor, thus a close linkages between both factors is very natural and would reflect in the behavioral tendency of employees. Coping increases the level of commitment of every cadre of employees, which in turn exercise favorable impact on personal growth of employees and organization too. Cohen (1992) reported that employees holding higher status, the relationship with the organization could be characterized as an exchange relationship. These employees will be committed to the organization only if the organization meets their expectations relating to their job and occupations. These aspects may include specific features of the job, such s autonomy un ambiguity in job role, features of the organizational structure, such as decentralization and better flow of organization communication, and positive work experiences, such as effective leadership. Higher level employees want more autonomy in their job, and opportunity to use their skills and potential in their work. This could be possible only when there would be better job characteristics and adequate organizational structure .The quality of organizational process has a significant impact on commitment to organization. Singh (2010) reported that active and adaptive coping strategies of police employees were significant favorable predictors on organizational commitment of police employees. Tiwari (2007) reported active and adaptive coping strategies played a significance role for making high commitment level towards organization. Shahnawaz and Jafri (2009) explored psychological capital / capacities as a predictor of organizational commitment between public and private sector organizations. The results are also supported by the earlier work of Hurter (2008) who found that professional commitment that is conceptually similar to the organizational commitment was positively related with self efficacy. The results are also revealed that the employees, who have higher level of self efficacy, have higher level of employee commitment. Active and adaptive coping strategies are mostly near with self efficacy. Akhtar Saleem et al (2013) reported that self efficacy as a predictor of organizational commitment of bank employees. Luthans and Youssef (2007) found that organizational commitment is positively related with hope, optimism nd resilience whereas Hurter (2008) and Sinha, Talwar and Rajpal (2002) found self efficacy as positive correlates of organizational commitment. Bogler Somech's study (2004) that found self efficacy as significant predictor of organizational and professional commitment. Another studies, it has been found that there is positive relationship between the personal attribution of internality and organizational commitment (Achamamba and Gopikumar, 1990; Spector, 1982). Studies reveal that locus of 


\section{Coping as Predictor of Organizational Commitment of Police Employees}

control is associated with various other job attitudes. It has been found that those who have an internal locus of control expressed higher job involvement (Pathak, 1982).

Therefore, it may be said that there is need to use more active and adaptive coping strategies for making high commitment level of constables and sub-inspectors towards organization. Whereas, officers should maximize their active and adaptive related strategies for creating commitment level. Although, employees of all cadre should avoid for using their maladaptive related coping strategies. Finally, it can be clearly proved the pervasive impact of coping in promotion of organizational commitment in police employees is justified on the basis of present findings.

\section{REFERENCES}

Achamamba, B., and Gopikumar, K. (1990). Locus of control and job involvement among men and women bank employees. Indian Journal of Applied Psychology, 27, 6-9.

Akhtar, S., Ghayas, S., \& Adil, A. (2013). Self efficacy and optism as predictors of organizational commitment among bank employees. International Journal of Research Studies in Psychology, 33-42

Angle, H.L., and Perry, J.L. (1981). An empirical assessment of organizational commitment and organizational effectiveness. Administrative Science Quarterly, 21, 1-14.

Bogler, R., Somech, A. (2004). Influence of teacher empowerment on teachers' organizational commitment, professional commitment and organizational citizenship behavior in schools. Journal of Teaching and Teacher Education, 20, 277-289.

Buchanan, B. (1974). Building organizational commitment: The socialization of managers in work organization. Administrative Science Quarterly, 19, 533 - 546.

Carver,C.S., Scheiver, M.F., and Weintraub, J.G (1989). Assessing coping strategies : A theoretical based approach. Journal of Personality and Social Psychology, 56, 267- 283.

Cohen, A.(1992). Antecedents of organizational commitment across occupational groups: A meta analysis. Journal of Organizational Behaviour, 13, 539- 558.

Cohen, F., \& Lazarus , r. (1979). Coping with the stresses of illness. In G.C. Stone, E. Cohen, \& N.E. Adler (Eds.) Health Psychology : A Handbook. San Francisco : Jossey- Bass.

Das, G.S.(1983). Some correlates of managerial job involvement: Implication for work recognization. Decision, 10, 51- 60.

Hurter, N. (2008). The role of self efficacy in employee commitment. Unpublished masterl thesis, University of South Africa, South Africa

Iun, J., \& Huang, X. (2007). How to motivate your older employees' performance in the hospitality industry. International Journal of Hospitality Management, 26, 793-806.

Khan, S.M., \& Mishra, P.C. (2002). Tips of Bang on avoidance behavior-an experience with railway officers. Journel of Indian Academy of Applied Psychology. Vol.28 No. 1-2, 131-138.

Kulkarni, A. V. (1983). Relationship between internal versus external locus of control and job satisfaction. Journal of Psychological Research, 27,57 - 60. 


\section{Coping as Predictor of Organizational Commitment of Police Employees}

Kulkarni, A.V. (1980). Belief system and job satisfaction : A study of bank and insurance officers. Prajnan, 9, 281 - 285.

Lazarus, R.S., and Folkman, S(1984). Coping and adaptation. In W.D. Gentry (ed.). The Handbook of Behavioural Medicine. New York : Guilford.

Luthans, F., \& Youssef, C.M (2007). Emerging positive organizational behavior. Journal of Management,33,321-349.

Mathieu, J.E., \& Zajac, D.M. (1990). A review and meta- analysis of the antecedents, correlates, and consequences of organizational commitment, Psychological Bulletin, 108, 171 - 194.

Meyer, J.P., \& Allen , N.J. (1991). A three component conceptualization of organizational commitment. Human Resource Management Review,1,61-89.

Meyer, J.P., \& Allen , N.J. (1997). Commitment in the Workplace: Theory, research, and application. Newbury Park, CA: SAGE.

Meyer, J.P., \& Allen, N.J. (1984). Testing the 'side- bet theory' of organizational commitment: Some methodological considerations. Journal of Applied Psychology, 69, 372 - 378.

Meyer, J.P., Allen, N.J. and Smith, C.A. (1993). Commitment to organizations and occupational extension and test of a three component conceptualization. Journal of Applied Psychology. 78(4),538-551.

Meyer, J.P., Stanley, D.J., Herscovitch, L., \& Topolnytsky, L. (2002). Affective, continuance, and normative commitment to the organization : A meta analysis of antecedents, correlates, and consequences. Journal of Vocational Behaviour, 61, 20 - 52.

Meyer,J.P., \& Herscovitch,L. (2001). Commitment in the workplace : Toward a general model. Human Resource Management Review,11, 299 - 326.

Morris, J.H., \& Sherman, J.D. (1981). Generalizability of an organizational commitment model. Academy of Management Journal, 24, 512 -526.

Mottaz, C.J. (1988). Determinants of organizational commitment. Human Relations, 41, 467482.

Mowday, R.T., Porter, L.W., \& Steers, R.M. (1982). Employee - organizational linkages: The Psychology of commitment. New York: Academic.

Mowday, R.T., Steers, R.M., \& Porter, L.W. (1979). The measurement of organizational commitment. Journal of Vocational Behaviour, 14, 224-247.

Padaki, R. (1982). Organizational climate and work behavior. Unpublished doctoral dissertation, Gujarat University, Ahmedabad.

Pandey, A., \& Mandal, S.K. (1990). Employee age as a moderator of the relation between absence of work alternatives and job satisfaction on Indian railways. Indian Journal of Applied Psychology, 27, 92-97.

Pathak, R.D. (1982). Job involvement: Its relationships to certain variables among bank officers in India. Prajnan, 11, 269-282.

Shahnawaz, G. S., \& Jafri, H.S. (2009). Psychological capital as predictors of organizational commitment and organizational citizenship behavior. Journal of the Indian Academy of Applied Psychology, 35, 78 - 84. 


\section{Coping as Predictor of Organizational Commitment of Police Employees}

Sharma, S., \& Kapoor, V. K. (1978). A study of job involvement in relation to certain demographic variables among white- collar workers. Indian Psychological Review, 16, 11-16.

Sharma, S., \& Sharma, R.K. (1978). A study of job involvement in relation to certain demographic variables among engineers. Indian Journal of Industrial Relations, 14, 141 - 148.

Sinclair, R.R., Tucker, J.S., Callen, J.C., \& Wright, C. (2005). Performance differences among four organizational commitment profiles. Journal of Applied Psychology, 90, 1280 - 1287.

Singh, A. P. (2010). Modifying role of perceived control and coping in the work stresscommitment relationship. Published Doctoral Dissertation. DDU Gorakhpur University, Gorakhpur.

Singhal, S., \& Sood, R. (1981). Control in hospital and occupational commitment of nurses. Managerial Psychology, 2, 51-59.

Sinha, P. S., Talwar, T., \& Rajpal, R. (2002). Co- relational study of organizational commitment, self efficacy and psychological barriers to techonological change. Psychologia, 45(3), 176 - 183 .

Spector, P. E. (1982). Behaviour in organization as a function of employees locus of control. Psychological Bulletin, 41, 482- 497.

Steers, R.M. (1977). Antecedents and outcomes of organizational commitment. Administrative Science Quarterly, 22, 46-56.

Suman, S., \& Srivastava , A.K., (2012) Antecedents of Organizational Commitment across hierarchical levels. Psychology and Developing Societies, Sage Publication, Allahabad, 61-83

Super, D.E. (1980). A life- span , life- space approach to career development. Journal of Vocational Behavior, 16, 282-298.

Tiwari, S. K. and Mishra, P.C. (2008). Work stress and Health as predictors of Organizational commitment. Indian Academy of Applied Psychology.

Tiwari, S.K. (2006). Psychological Correlates of Organizational Commitment : A Study on Railway Personnel. Published Doctoral Dissertation. Lucknow University, Lucknow.

Van Dick, R. (2004). My job is my castle: Identification in organizational contexts. In C. L. Cooper \& I.T. Robertson (Eds.), International review of individual and organizational psychology (Vol. 19, pp. 171 - 203). Chichester: Wiley.

How to cite this article: A Singh (2016), Coping as Predictor of Organizational Commitment of Police Employees, International Journal of Indian Psychology, Volume 3, Issue 4, No. 60, ISSN 2348-5396 (e), ISSN: 2349-3429 (p), DIP: 18.01.096/20160304, ISBN: 978-1-365-26308-8

(C) The International Journal of Indian Psychology, ISSN 2348-5396 (e)| ISSN: 2349-3429 (p) | 200 